\title{
Influence of nutrient sources on growth, yield and economics of organic lettuce production under foothills of eastern Himalayan region
}

\author{
Ranjit Chatterjee \\ Department of Vegetable and Spice Crops, Uttar Banga Krishi Viswavidyalaya, Pundibari, Cooch Behar-736165 (W.B), India
}

\section{A B S T R A C T}

\begin{abstract}
Lettuce is a high value salad vegetable rich in minerals, vitamins and antioxidants. With the increasing awareness on ill effect of chemicals on human health and environment, the demand for residue free organic lettuce is increased sharply. Traditionally farmers are using farmyard manure (FYM) as source of nutrients for organic lettuce cultivation. But higher cost and scarcity of the animal manure forcing the farmers to search alternate nutrient source for organic lettuce cultivation. Keeping the fact in mind an experiment was carried out to find out an alternate source of farmyard manure or substituted a portion to reduce the pressure on sole farmyard manure. The inputs namely farmyard manure and vermicompost were used sole as well as in combination of Azotobacter and Phosphate Solubilizing Bacteria containing biofertlizer (Azophos). Six numbers of treatments were laid out in randomized block design (RBD) with 4 replications. The seedlings of head type lettuce variety Great Lakes were transplanted in mid November for two years in the plot size of $3 \mathrm{~m} \times 3 \mathrm{~m}$. The pooled results revealed that all the yield attributing characters were influenced by treatments variation and the treatment combination comprised of FYM (10 t ha-1) and vermicompost $\left(2.5 \mathrm{t} \mathrm{ha}^{-1}\right)$ inoculated with biofertilizer recorded the maximum number of leaves (18.42 plant $\left.{ }^{-1}\right)$ and chlorophyll content (39 SPAD value) and fresh weight of head (334 $\mathrm{g} \mathrm{plant}^{-1}$ ). Application of vermicompost $\left(5 \mathrm{t} \mathrm{ha}^{-1}\right)$ inoculated with Azophos emerged as second best combination for most of the yield and yield attributing traits for organic lettuce production.
\end{abstract}

Keywords: Organic production; Nutrient sources; Lettuce growth; Yield

\section{INTRODUCTION}

Lettuce (Lactuca sativa L.) is a high value salad vegetable belongs to family Compositae. The head and leaves are rich in several minerals, vitamins and important source of dietary antioxidants (Ke and Saltveit, 1988; Nicolle et al., 2004). With the increasing awareness on ill effect of chemical faming on human health and environment, the demand of organic lettuce for salad and other preparation is increasing sharply both in domestic and international market. Farmers are gradually adopting organic lettuce cultivation in the foothill of eastern Himalayan region during the winter months. Being a short duration crop, lettuce demands heavy manuring for potential growth and yield. However traditionally farmyard manure is used as source of nutrients for organic lettuce cultivation. But higher cost and scarcity of the animal manure forcing the farmers to search alternate nutrient source.
Vermicompost, a popular organic manure contains nutrients in form that are readily taken up by the plants such as nitrates, exchangeable phosphorus, and soluble potassium, calcium, and magnesium (Edwards and Burrows, 1988). Atiyeh et al. (2002) reported increased plant growth, higher yield and better quality produce with the vericompsot application as the water soluble components of vermicompost like humic acid, growth regulators, vitamins and micronutrients enhanced the availability of plant nutrients. Apart from farmyard manure and vermicompost, biofertilizer plays significant role as organic nutrient source for sustainable soil health and crop growth in vegetable crops (Bhattacharya et al., 2000). The present study was aimed to find an alternate source of farmyard manure or substitute a portion through vermicompost and biofertilizer to form an effective nutrient schedule for organic lettuce production in the foothills of eastern Himalayan region.

\footnotetext{
${ }^{*}$ Corresponding author:

Ranjit Chatterjee, Department of Vegetable and Spice Crops. Uttar Banga Krishi Viswavidyalaya, Pundibari, Cooch Behar-736165 (W.B), India. E-mail: ranchat22@rediffmail.com
} 


\section{MATERIALS AND METHODS}

The experiment was carried out at the instructional farm of Uttar Banga Krishi Viswavidyalaya, Pundibari, Coochbehar, West Bengal, India (26 $19^{\prime} 86^{\prime \prime} \mathrm{N}$ latitude and 89 23'53" E longitude and $43 \mathrm{~m}$ above MSL). The crop was raised during winter months of 2009-10 and 2010-11. The soil was well drained sandy loam having $\mathrm{pH}$ of 5.78 , organic carbon content $0.88 \%$ and available $\mathrm{N}, \mathrm{P}_{2} \mathrm{O}_{5}, \mathrm{~K}_{2} \mathrm{O}$, were $212.41 \mathrm{~kg}$ $\mathrm{ha}^{-1}, 18.32 \mathrm{~kg} \mathrm{ha}^{-1}, 103.16 \mathrm{~kg} \mathrm{ha}^{-1}$ respectively. The treatments were $\mathrm{T}_{1}$ - farmyard manure $\left(20 \mathrm{t} \mathrm{ha}{ }^{-1}\right) ; \mathrm{T}_{2}$-vermicompost $\left(5 \mathrm{t} \mathrm{ha}^{-1}\right) ; \mathrm{T}_{3}$ farmyard manure $\left(10 \mathrm{tha}^{-1}\right)+$ vermicompost $\left(2.5 \mathrm{t} \mathrm{ha}^{-1}\right) ; \mathrm{T}_{4}$ farmyard manure $\left(20 \mathrm{t} \mathrm{ha}^{-1}\right)+$ biofertilizer; $\mathrm{T}_{5}$ vermicompost $\left(5 \mathrm{t} \mathrm{ha}^{-1}\right)+$ biofertilizer; $\mathrm{T}_{6}$ - farmyard manure $\left(10\right.$ tha $\left.^{-1}\right)+$ vermicompost $\left(2.5 t \mathrm{a}^{-1}\right)+$ biofertilizer. Thus 6 treatment combinations were laid out in Randomized Block Design (RBD) with 4 replications. Thirty days lettuce seedlings of the variety Great Lakes were planted in $3 \mathrm{~m} \times$ $2.25 \mathrm{~m}$ plots with spacing of $60 \mathrm{~cm} \times 45 \mathrm{~cm}$. Vermicompost and farmyard manure were applied to the respective plots 15 days before transplanting. Azophos, a commercial biofertilizer preparation containing the azotobacter and phosphate solubilizing bacteria was applied through seeding dipping using rice gruel as adhesive. The crop was raised adopting standard cultural practices. The observations were recorded on six different growth and yield attributes of lettuce. Leaf chlorophyll content was determined by using the Soil Plant Association Development (SPAD) 502 meter (Minolta Corporation, Japan). The area of leaves was measured by using the instrument Leaf area meter (Model 22, Systronics). The economics of the treatment was worked out on the basis of inputs and output cost as per existing market rate. Two years data collected on various parameters were pooled and statistically analyzed as per method suggested by Panse and Sukhatme (2000).

\section{RESULTS AND DISCUSSION}

The results revealed that nutrient combination markedly influenced the different growth and yield attributes of lettuce. The pooled data (Table 1) showed that the maximum number of leaves (18.42 plant $\left.^{-1}\right)$ with highest leaf chlorophyll (39 SPAD value) and leaf area $\left(319 \mathrm{~cm}^{2}\right)$ were registered when seedling were inoculated with Azotobacter and phosphate solubilizing bacteria containing biofertilizer and half of the dose of farmyard manure $\left(10 \mathrm{tha}^{-1}\right)$ and vermicompost $\left(2.5 \mathrm{tha}^{-1}\right)$ were applied to the crop $\left(\mathrm{T}_{0}\right)$. The magnitude of increase for leaf number and leaf area being $38 \%$ and $34 \%$ respectively in $\mathrm{T}_{6}$ over the sole application of $20 \mathrm{t} \mathrm{ha}{ }^{-1}$ farmyard manure $\left(\mathrm{T}_{1}\right)$. The data on days to head maturity showed distinct differences between nutrient sources and integration of farmyard manure $\left(10 \mathrm{t} \mathrm{ha}^{-1}\right)$, vermicompost $\left(2.5 \mathrm{t} \mathrm{ha}^{-1}\right)$ in presence of biofertilizer significantly reduced the head maturity days compared to others. The treatment $\mathrm{T}_{6}$ showed $12 \%$ advancement over the treatment $\mathrm{T}_{1}$. Earliness in head maturity in farmyard manure, vermicompost and biofertilizer loaded treatments could be attributed to enhanced vegetative growth coupled with adequate reserved food material which facilitated early differentiation of vegetative buds results in advance head development and maturity. Combined use of farmyard manure $\left(10 \mathrm{tha}^{-1}\right)$, vermicompost $\left(2.5 \mathrm{tha}^{-1}\right)$ in presence of biofertilizer also proved its superiority for head weight and green biomass yield of lettuce. The findings indicated that substitution of $50 \%$ farmyard manure with vermicompost and biofertilizers have pronounced influenced on head weight and green biomass yield of lettuce. The maximum head weight (334 g) and green biomass yield (412 $\mathrm{g}$ plant $\left.^{-1}\right)$ were recorded by the treatment $T_{6}$ followed by the treatment composed of vermicompost $\left(5 \mathrm{tha}^{-1}\right)$ inoculated with biofertilizers $\left(T_{5}\right)$. The findings further showed that performance of biofertilizer was influenced by the form of nutrient applied. Application of half of the farmyard manure and vermicompost in presence of biofertilizer $\left(\mathrm{T}_{0}\right)$ resulted in 34\% more leaf number and $27 \%$ more head weight over the uninoculated treatment $\mathrm{T}_{3}$. Again biofertilizer inoculated sole vermicompost $\left(\mathrm{T}_{5}\right)$ recorded $8 \%$ more leaf number and $4 \%$ higher head weight over the biofertilizer inoculated sole farmyard manure $\left(\mathrm{T}_{4}\right)$. The yield improvement with the combined application of farmyard manure and vermicompost in presence of biofertilizer may be attributed to the greater nutrient uptake and availability throughout the growth period. The

Table 1: Influence of nutrient sources on growth and yield of organic lettuce (Pooled mean of 2 years)

\begin{tabular}{|c|c|c|c|c|c|c|c|}
\hline Treatments & $\begin{array}{c}\text { Number of } \\
\text { leaves } \text { plant }^{-1}\end{array}$ & $\begin{array}{l}\text { Leaf chlorophyll } \\
\text { (SPAD value) }\end{array}$ & $\begin{array}{l}\text { Leaf area } \\
\left(\mathrm{cm}^{2}\right)\end{array}$ & $\begin{array}{l}\text { Days to head } \\
\text { maturity }\end{array}$ & $\begin{array}{c}\text { Head } \\
\text { weight }(g)\end{array}$ & 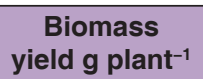 & $\begin{array}{c}\text { Biomass } \\
\text { yield } t \text { ha }^{-1}\end{array}$ \\
\hline$\overline{T_{1}}$ & 11.47 & 28 & 210 & 61.12 & 228 & 267 & 11.64 \\
\hline $\mathrm{T}_{2}$ & 13.24 & 33 & 251 & 57.84 & 274 & 318 & 12.89 \\
\hline $\mathrm{T}_{3}$ & 12.16 & 30 & 234 & 59.24 & 251 & 291 & 12.14 \\
\hline $\mathrm{T}_{4}$ & 14.89 & 35 & 274 & 56.11 & 296 & 358 & 13.68 \\
\hline $\mathrm{T}_{5}$ & 16.19 & 37 & 286 & 54.42 & 311 & 381 & 14.41 \\
\hline $\mathrm{T}_{6}$ & 18.42 & 39 & 319 & 52.16 & 334 & 412 & 15.22 \\
\hline S.Em $( \pm)$ & 0.62 & 0.64 & 1.42 & 0.76 & 1.73 & 1.97 & 0.66 \\
\hline$C D(P=0.05)$ & 1.82 & 1.89 & 4.23 & 2.24 & 5.14 & 5.86 & 1.94 \\
\hline
\end{tabular}

Treatment details are given in materials and methods 
increased uptake of essential plant nutrients is expected to enhance carbohydrate synthesis and effective translocation of these photosynthetes to the sink which is expressed in head weight and subsequently green biomass yield. Lee et al. (2004) stated that addition of manure compost increased total organic matter, macronutrient and micronutrient in the soil that helped in accumulation of fresh weight in lettuce.Workers like Pavlou et al. (2007) and Castro et al. (2009) also pointed that enhancement of head yield of lettuce under organic nutrient source may be attributed to increased macronutrients and organic matter content of the soil. Naidu et al. (2000) observed that application of farmyard manure and vermicompost in presence of biofertilizer harboured significantly more microbes in soil. Beneficial effect of vermicompost in lettuce was also documented by Ali et al. (2007). The economics of production (Table 2) revealed that application of half of the farmyard manure and vermicompost in presence of biofertilizer $\left(\mathrm{T}_{6}\right)$ fetched the maximum net return with highest benefit cost ratio (3.45) followed by $\mathrm{T}_{4}$ with benefit cost ratio 3.38. The result also suggested that use of biofertilizer with the traditional practice $\left(\mathrm{T}_{1}\right)$ will bring higher net income and more benefits. The lowest benefit cost ratio sole vermicompost containing treatment may be due to higher cost of vermicompost over the farmyard manure.

\section{CONCLUSION}

The experimental result clearly demonstrated that source of nutrient have significant positive influence on the performance of organic lettuce. In addition to farmyard manure, vermicompost and $\mathrm{N}$-fixing \& $\mathrm{P}$ solubilizing biofertilizers have significant contribution on the growth attributes and green biomass yield. Combined use of farmyard manure $\left(10 \mathrm{t} \mathrm{ha}^{-1}\right)$, vermicompost $\left(2.5 \mathrm{t} \mathrm{ha}^{-1}\right)$ in presence of Azotobacter and phosphate solubilizing bacteria

Table 2: Economics of production for different nutrient sources on organic lettuce

\begin{tabular}{lccccc}
\hline Treatments & $\begin{array}{c}\text { Biomass } \\
\text { yield } \\
\text { t ha }^{-1}\end{array}$ & $\begin{array}{c}\text { Gross } \\
\text { return } \\
\left.\text { (Rs ha }^{-1}\right)^{*}\end{array}$ & $\begin{array}{c}\text { Cost of } \\
\text { cultivation } \\
\left.\text { (Rs ha }^{-1}\right)\end{array}$ & $\begin{array}{c}\text { Net } \\
\text { return } \\
\text { (Rs ha }^{-1} \text { ) }\end{array}$ & $\begin{array}{c}\text { B:C } \\
\text { ratio }\end{array}$ \\
\hline $\mathrm{T}_{1}$ & 11.64 & 232800.00 & 58162.00 & 174638.00 & 3.00 \\
$\mathrm{~T}_{2}$ & 12.89 & 257800.00 & 71242.00 & 186558.00 & 2.62 \\
$\mathrm{~T}_{3}$ & 12.14 & 242800.00 & 65816.00 & 176984.00 & 2.69 \\
$\mathrm{~T}_{4}$ & 13.68 & 273600.00 & 62526.00 & 213274.00 & 3.38 \\
$\mathrm{~T}_{5}$ & 14.41 & 288200.00 & 77090.00 & 222910.00 & 2.74 \\
$\mathrm{~T}_{6}$ & 15.22 & 304400.00 & 68368.00 & 237032.00 & 3.45 \\
\hline *The
\end{tabular}

The sale rate of lettuce was Rs. 2000.00 per quintal containing biofertilizers proved its superiority over sole application of farmyard manure $\left(20 \mathrm{t} \mathrm{ha}^{-1}\right)$ for all the attributes studied and the same may be adopted for large scale organic lettuce production. The enhancement of growth and biomass yield will result in better remuneration from organic cultivation and subsequently will encourage using different nutrient sources that will help in sustaining the fertility and productivity of soil.

\section{ACKNOWLEDGMENTS}

The author duly acknowledge the technical and financial assistance from the University Uttar Banga Krishi Viswavidyalaya for conducting the research experiment.

\section{REFERENCES}

Ali, M., J. G. Anthony, P. W. Keith and L. J. Davey. 2007. Evaluating the growth characteristics of lettuce in vermin compost and green waste compost. Eur. J. Soil Bio. 43: 316-319.

Atiyeh, R. M., S. S. Lee, C. A. Edwards, N. Q. Arancon and J. Metzger. 2002. The influence of humic acid derived from earthwormprocessed organic waste on plant growth. Bioresour. Technol. 84: 7-14.

Bhattacharya, P., R. K. Jain and M. K. Paliwal. 2000. Biofertilizers for vegetables. Indian Hort. (July-September issue) ICAR Publication, New Delhi, India.

Castro, E., P. Manas and J. D. L. Heras. 2009. A comparison of the application of different waste products to a lettuce crop: Effects on plant and soil properties. Sci. Hort. 123: 148-155.

Edwards, C. A. and I. Burrows. 1988. The potential of earthworm composts as plant growth media. In: Edwards C A and Neuhauser E. Editors. Earthworms in Waste and Environmental Management. SPB Academic Press, Hague, Netherlands. p. 21-32.

Ke, D., M. E. Saltveit. 1988. Plant hormone interaction and phenolic metabolism in the regulation of russet spotting in iceberg lettuce. Plant Physiol. 88: 1136-1140.

Lee, J. J., R. D. Park, Y. W. Kim, T. H. Kim and K. Y. Kim. 2004. Effect of food waste compost on microbial population, soil enzyme activity and lettuce growth. Bioresour. Tech. 93: 21-28.

Naidu, A. K., S. S. Kushwah and Y. C. Dwivedi. 2000. Performance of organic manures, bio and chemical fertilizers and their combinations on microbial population of soil and growth and yield of okra. JNKVV Res. J. 33: 34-38.

Nicolle, C,. A. Carnat, D. Fraisse, J. Lamaison, E. Rock, H. Michel, P. Amouroux and C. Remesy. 2004. Characterisation and variation of antioxidant micronutrients in lettuce. J. Sci. Food Agri. 84: 2061-2069.

Panse, V. G and P. V. Sukhatme. 2000. Statistical Methods for Agricultural Workers. ICAR Publications, New Delhi, India.

Pavlou, G. C., C. D. Ehaliotis and V. A. Kavvadias. 2007. Effect of organic and inorganic fertilizers applied during successive crop seasons on growth and nitrate accumulation in lettuce. Sci. Hortic. 111: 319-325. 